\title{
ARTYKUŁY
}

Klio. Czasopismo poświęcone dziejom Polski i powszechnym

PL ISSN 1643-8191, t. 56 (4)/2020, s. 65-88

(1) $\odot$

http://dx.doi.org/10.12775/KLIO.2020.061

MareK AdAmCZewshi

\section{Wyobrażenia na pieczęciach władz i urzędów miejskich w Księstuie Warszawskim Kilka uwag na temat jednego faktu}

\author{
Images on the seals of city authorities and offices \\ in the Duchy of Warsaw \\ Some remarks on one fact
}

Streszczenie: Marian Gumowski w 1960 r. w swoich publikacjach przywołał rozporządzenie rządu Księstwa Warszawskiego z 28 kwietnia 1811 r., na mocy którego pieczęcie władz i urzędów miejskich miały otrzymać wyobrażenie składające się z herbu księstwa. Po upływie 60 lat od opublikowania informacji o rozporządzeniu z kwietnia 1811 r. zostały przeprowadzone badania, których wyniki kwestionują twierdzenie Gumowskiego. Decyzję w sprawie wyobrażeń pieczęci władz i urzędów w miastach podjął w 1809 r. minister spraw wewnętrznych księstwa $\mathrm{i}$ - odwołując się do obowiązującego prawa o samorządzie gminnym - uznał, że prezydenci i burmistrzowie powinni mieć pieczęcie z herbem księstwa, a rady miejskie - pieczęcie z herbem miasta.

* Instytut Historii Uniwersytetu Łódzkiego, ul. A. Kamińskiego 27a, 90-220 Łódź, ada.marek@interia.pl, ORCID: 0000-0002-7230-5220. 
Abstract: In 1960 Marian Gumowski described the content of the regulation of April 1811. The ordinance - as Marian Gumowski claimed - contained the order to introduce the state coat of arms on the fields of all city seals. Currently conducted research did not confirm the thesis of 1960. In 1809, the Minister of the Interior issued an ordinance regarding city seals. The minister ordered that the mayor's seals be marked with the coat of arms of the state, and the seals of the cities councils - with the coat of arms of the city.

Słowa kluczowe: pieczęć, Księstwo Warszawskie, Marian Gumowski

Keywords: seal, Duchy of Warsaw, Marian Gumowski

Drzedmiotem w badaniach historycznych są przede wszystkim fakty hi1 storyczne, nazywane niekiedy faktami dziejowymi, które mogą układać się w ciąg przyczynowo-skutkowy $\mathrm{i}$ - analizowane łącznie w wielkiej liczbie następujących po sobie i związanych ze sobą zdarzeń - stają się wydarzeniami historycznymi. Nie wchodząc w zbędne tu - ze względu na zakres podjętych badań - zawiłości metodologii historii ${ }^{1}$, wyjaśniam, że za fakt historyczny - zgodnie z pozytywistycznym spojrzeniem na rolę historyka - przyjmuję tylko ten fakt, który w sposób bezpośredni został odnotowany w wiarygodnym źródle historycznym. Jerzy Topolski zauważył, że fakt historyczny - w rozumieniu pozytywistycznym - jest obiektywnym przedmiotem badania, tj. niezależnym od czynności podejmowanych przez „podmiot poznający”.

W pewnej opozycji wobec faktu historycznego pozostaje (wzmiankowany w literaturze) fakt historiograficzny. Za fakt historiograficzny można uznać informację na temat zdarzenia z przeszłości zgłoszoną przez badacza lub znawcę problemu, która została przez badacza lub znawcę „odkryta” $\mathrm{w}$ drodze wnioskowania pośredniego w procedurze akceptowalnej w ramach badań historycznych i następnie została spopularyzowana w publikacjach. Jerzy Topolski w kontekście faktu historiograficznego pisał o „konstrukcji

1 W. Moszczeńska, Metodologii historii zarys krytyczny, Warszawa 1977, s. 55 i nast.; J. Topolski, Metodologia historii, Warszawa 1973, s. 196. 
naukowej” czy też o „ujęciu zdarzenia” przez osobę zgłębiającą zagadnienie, a także o „rekonstrukcji faktu”.

Fakt historiograficzny (fakt „zrekonstruowany”) jest wynikiem dojrzałej refleksji badacza lub znawcy i w warunkach deficytu podstawy źródłowej staje się istotnym uzupełnieniem narracji historycznej. Na marginesie prowadzonych tu rozważań należy przypomnieć, że ustalenia dokonane w ramach postępowania pośredniego nie mogą pozostawać w sprzeczności z konkluzjami wypływającymi bezpośrednio z treści wiarygodnego źródła historycznego.

Nie zamierzam wartościować rodzajów faktów i udowadniać wyższości faktu historycznego nad „erudycyjnym” czy też „zrekonstruowanym” faktem historiograficznym ani też nie zamierzam przyjąć odwróconej perspektywy. W instrumentarium historyka i w budowanej przez niego opowieści na temat przeszłości fakty historyczne harmonijnie mogą przeplatać się z faktami historiograficznymi, tworząc zwartą opowieść o wydarzeniach, ludziach czy też o instytucjach. W dalszym tekście zwrócę uwagę jedynie na odpowiedzialność badacza lub znawcy, który rekonstruuje fakt, a następnie wprowadza go do obiegu naukowego. Popełniając błąd w trakcie wnioskowania lub - co gorsza - świadomie tworząc nieistniejący „byt”, badacz lub znawca dopuszcza się deliktu naukowego, co w konsekwencji podważa zaufanie do badań i kwestionuje sens sztafety wiedzy czy też sens wznoszenia gmachu wiedzy na ramionach „gigantów”.

Jeden fakt historiograficzny z zakresu sfragistyki miejskiej, w tym przypadku twierdzenie o jednostkowym zdarzeniu o znaczeniu normatywnym z przeszłości, opisane przez badacza o uznanym dorobku w ważnym dla heraldyki miejskiej wydawnictwie, zostało przyjęte przez innych badaczy i znawców za kluczowe i nie było kwestionowane w dotychczasowej literaturze. Tym faktem historiograficznym czy też rekonstrukcją faktu, który w dalszym tekście zostanie pozbawiony części wiarygodności, jest zdanie Mariana Gumowskiego na temat wyobrażeń pieczęci władz i urzędów funkcjonujących w miastach Księstwa Warszawskiego². Informacja prze-

2 „[...] rząd Księstwa Warszawskiego, dekretem z 29 kwietnia 1811 r. [...] zabronił miastom swojego terytorium używać dawnych herbów lokalnych, a wszystkie pieczęcie miejskie nakazał zaopatrzyć w herb państwowy"; M. Gumowski, Herby miast polskich, 
kazana przez Mariana Gumowskiego - co istotne dla jej recepcji i popularności - racjonalnie objaśniała strukturę systemu sfragistycznego Księstwa Warszawskiego i ikonografię pieczęci wówczas wytwarzanych, tj. uzupełniała w sposób oczekiwany przez badaczy i znawców ustalenia wywiedzione z oglądu zachowanych i rozpoznanych pieczęci.

Konkluzje Mariana Gumowskiego szeroko przedostały się do wydawnictw o różnym charakterze - do podręczników³, opracowań monograficznych, w tym do opracowań na temat znaków poszczególnych samorządów ${ }^{4}$, a także do opisów zespołów pieczęci miejskich z lat 1807-1815. Ustalenia badacza ukierunkowały wnioskowanie przynajmniej dwóch pokoleń historyków (1960-2020) zajmujących się nowożytną sfragistyką miejską w Polsce. W 2013 r. ukazała się ważna publikacja na temat prac Mariana Gumowskiego w zakresie sfragistyki i heraldyki miejskiej ${ }^{5}$ Wątek pieczęci

Warszawa 1960, s. 14. Marian Gumowski opinię na temat rządowej decyzji w sprawie pieczęci spopularyzował w 1960 r., czyli w 2020 r. mija 60 lat od wprowadzenia jej do obiegu naukowego. Wydaje się, że 60. rocznica zdarzenia jest dobrą okazją do krytycznego zbadania poprawności zacytowanego wyżej zdania. Pewne znaczenie ma także miejsce publikacji tekstu rewidującego ustalenia Mariana Gumowskiego. W 1960 r. Marian Gumowski był związany z uniwersytetem toruńskim i dziś najlepszym miejscem do publikacji uwag korygujących ustalenia profesora z Torunia jest periodyk toruńskiej historii.

3 „Wiele miasteczek mniejszych zapomniało o swoich dawnych herbach i w XIX w. pieczętowało się herbem państwowym. Było to wynikiem tego, że już w 1811 r. rząd Księstwa Warszawskiego wezwał wszystkie miasta do porzucenia starych i sprawienia sobie nowych pieczęci z herbem Księstwa”; Sfragistyka, oprac. M. Gumowski, M. Haisig, S. Mikucki, Warszawa 1960, s. 241 (część podręcznika, w której znalazły się uwagi o „prawie sfragistycznym” Księstwa Warszawskiego, opracował Marian Gumowski); „Własnych pieczęci zabroniono miastom używać w Księstwie Warszawskim"; J. Szymański, Nauki pomocnicze historii, Warszawa 1983, s. 649; idem, Nauki pomocnicze historii, Warszawa 2008, s. 625.

4 „W 1811 r. władze Księstwa dekretem z 28 kwietnia [s] wprowadzity zasadę jednolitości pieczęci miejskich, według której herby lokalne zastąpiono sasko-polskim herbem państwowym"; K. Dorcz, Herb miasta Końskie w okresie zaborów (1795-1918), w: Herby miast polskich w okresie zaborów (1772-1918). Materiaty sesji naukowej, Wtoctawek 5-6 grudnia 1996 r., red. S. K. Kuczyński, Włocławek 1999, s. 162.

5 H. Seroka, Osiagnięcia prof. Mariana Gumowskiego na polu sfragistyki i heraldyki miejskiej Polski, „Rocznik Polskiego Towarzystwa Heraldycznego” 2013, t. 12 (23), s. 133-146 . 
władz i urzędów miejskich z okresu Księstwa Warszawskiego nie został zauważony.

Szczególne znaczenie w procesie akceptacji stwierdzenia Mariana Gumowskiego z 1960 r. w sprawie ujednostajnienia pieczęci miejskich z okresu Księstwa Warszawskiego miały prace Stefana K. Kuczyńskiego. Stefan K. Kuczyński przyjął zdanie Mariana Gumowskiego i w swoich publikacjach przytaczał jego konkluzje lub wprost cytował fragmenty książki z 1960 r. dotyczące tendencji unifikacyjnych prowadzonych w kierunku narzucenia przez czynniki miarodajne księstwa oficjalnego herbu państwowego wszystkim dysponentom pieczęci urzędowych. Stefan K. Kuczyński do miejskich pieczęci z herbem sasko-polskim, o których pisał Marian Gumowski, dodał pieczęcie „samorządowych” władz szczebla wojewódzkiego i powiatowego (rady departamentów i rady powiatów), które (zgodnie z ówczesną literą prawa) funkcjonowały jako samorządowe struktury władzy w Księstwie Warszawskim ${ }^{6}$.

Zakres funkcji pieczęci władz i urzędów w Księstwie Warszawskim wykraczał poza oczywiste uwierzytelnienie dokumentu i techniczne zamknięcie korespondencji oznaczonym lakiem. Należy pamiętać, że - a wynika to $\mathrm{z}$ regulaminu pocztowego ${ }^{7}$ - korespondencja prowadzona przez władze i urzędy mogła być zwolniona z portorium (z opłaty pocztowej), ale przyznanie zwolnienia było konsekwencją odciśnięcia na liście „urzędowej pieczęci publicznej”. Tym samym stosowanie właściwej pieczęci przez

6 S. K. Kuczyński, Polskie herby ziemskie. Geneza, treści, funkcje, Warszawa 1993, s. 236. Stefan K. Kuczyński w innej pracy, z 1999 r., zarysował obraz ujednostajnionej sfragistyki księstwa, w ramach której wszystkie władze i urzędy funkcjonujące na obszarze księstwa posługiwały się pieczęciami z herbem sasko-polskim („W heraldyce księstwa panowała zasada unifikacji i centralizmu państwowego. Stosownie do tego herb państwowy był używany przez władze centralne księstwa oraz wszystkie jednostki podziału administracyjnego kraju - departamenty i ich prefektów, powiaty i podprefektów, rady departamentowe, powiatowe i municypalne, miasta i władze miejskie, wójtów, sołtysów oraz inne urzędy, instytucje i urzędników"; idem, Herby urzędowe na ziemiach polskich w okresie pozaborowym, w: Herby miast polskich w okresie zaborów (1772-1918)..., s. 14).

7 Wyiatek z Regulaminu pocztowego. O taxie pocztowey, o obowiazkach ptacenia portorium, o jazdach extrapocztowych i furmanach z dotaczeniem tabelli wszystkich kursów poczty w Księstwie Warszawskiem, [Warszawa] 1808, s. 14. 
władze i urzędy księstwa miało dla dysponentów urzędowych pieczęci także wymiar finansowy.

Ustalenia Mariana Gumowskiego z 1960 r. dotyczyły ściśle przyjęcia przez władze Księstwa Warszawskiego 29 kwietnia 1811 r. „dekretu” w sprawie formy pieczęci (głównie ikonografii) pieczęci władz i urzędów miejskich. Według badacza „dekret” z kwietnia 1811 r. ostatecznie przesądził o usunięciu historycznych, tj. staropolskich, oryginalnych, miejskich herbów przedrozbiorowych z pól pieczęci władz i urzędów miejskich i zdecydował o wprowadzeniu zamiast nich sasko-polskiego herbu państwowego Księstwa Warszawskiego. Zdanie wypowiedziane przez Mariana Gumowskiego - z powodu jego budowy (wskazanie autora regulacji prawnej, w tym przypadku - krajowej władzy wykonawczej, pełniącej ograniczone funkcje prawodawcze, podanie daty wydania aktu, a także ścisłe wskazanie obszaru prawnie uregulowanego) - sprawiało wrażenie, że analizowane tu zdanie było rodzajem skąpego, ale jednak wiernego omówienia odnalezionego i rozumnie przeanalizowanego aktu prawnego.

Historycy podążający za rozważaniami Mariana Gumowskiego i usiłujący potwierdzić czy też uściślić jego obserwacje dotyczące urzędowej sfragistyki księstwa nie natrafili jednak w zachowanej dokumentacji aktowej, a także w publikatorach rządowych na „dekret” z 29 kwietnia 1811 r. w sprawie wyobrażeń pieczęci władz i urzędów miejskich w księstwie. Autorytet naukowy Mariana Gumowskiego i przekonanie o wysokiej jakości badań przez niego prowadzonych, a także przeświadczenie o naukowej uczciwości badacza ${ }^{8}$ łącznie spowodowały, że historycy, nie mogąc odszukać „dekretu” z 29 kwietnia 1811 r., wbrew obowiązkowi zachowania krytycznej postawy właściwej postępowaniu naukowemu z niepewnym przekazem, zaczęli tłumaczyć, dlaczego „dekretu” z kwietnia 1811 r. nie można ponownie odnaleźć. W tym przypadku niepowodzenia miały być oczywistą konsekwencją drugiej wojny światowej. Według Stefana K. Kuczyńskiego

8 Krytyczną ocenę jakości badań Mariana Gumowskiego (w tym „naginanie” i „nakłanianie” faktów do „mniej lub więcej karkołomnej koncepcji”) zawiera opinia Zygmunta Zakrzewskiego z 1927 r. przygotowana dla dziekana Wydziału Humanistycznego Uniwersytetu Poznańskiego; G. Trafalski, „Marian Gumowski (1881-1974). Biografia naukowa”, Łódź 2020, maszynopis. 
Marian Gumowski w czasie kwerend prowadzonych w Warszawie w latach drugiej wojny światowej mógł badać źródła, które następnie spłonęły podczas powstania warszawskiego w 1944 r. lub później w trakcie metodycznego niszczenia stolicy po upadku powstania9 . To wyjaśnienie logicznie wpisywało się w naukową wiedzę na temat badań Mariana Gumowskiego w czasie drugiej wojny światowej. Marian Gumowski w okresie okupacji hitlerowskiej przeglądał i „fiszkował” m.in. Album herbów miast Królestwa Polskiego z 1847 r., który po sierpniu 1944 r. został zniszczony. Notatki Mariana Gumowskiego stanowią dziś podstawowe źródło wiedzy o Albumie herbów. Nikt w zasadzie nie podważa wiarygodności "kopi”" Albumu herbów sporządzonej przez Mariana Gumowskiego. Informacja o „dekrecie” z 29 kwietnia 1811 r. mogła zatem - co podkreśla literatura - pochodzić z zaginionej - podobnie jak Album herbów - sfragistyczno-heraldycznej dokumentacji z okresu księstwa.

Inni badacze zauważyli, że data wydania „dekretu” z 29 kwietnia 1811 r. jest zdecydowanie za późna w stosunku do faktografii ustalonej na podstawie analizy zachowanych odcisków pieczęci władz i urzędów Księstwa Warszawskiego oznaczonych sasko-polskim herbem księstwa (chronologia występowania odcisków pieczęci miejskich z herbem sasko-polskim), a także w stosunku do datacji pism wytworzonych w sprawach urzędowych pieczęci w kancelarii ministra spraw wewnętrznych i w kancelariach prefektów niektórych departamentów ${ }^{11}$. Sprzeczność ta została zatuszowana stwierdzeniem, że „dekret” w sprawie pieczęci władz i urzędów miejskich z 29 kwietnia 1811 r. mógł być urzędowym podsumowaniem wcześniej

9 S. K. Kuczyński, Herb Warszawy, Warszawa 1977, s. 135, przyp. 2.

10 W tekście świadomie zostało użyte słowo „kopia” i równie świadomie zostało ono ujęte w cudzysłów. Z formalnego punktu widzenia materiał zgromadzony przez Mariana Gumowskiego po zbadaniu Albumu herbów należy uznać za notatkę, choć notatkę możliwie wiernie powtarzającą rysunek herbu i jego opis sporządzony w połowie XIX w. w języku polskim. Heraldycy zajmujący się godłami miejskimi Królestwa Polskiego (Kongresowego) z zaufaniem wykorzystują zgromadzone w ten sposób dane, a odnalezione, urzędowo potwierdzone kopie pojedynczych stron Albumu herbów sporządzone przed wrześniem 1939 r. potwierdzają prawdziwość wtórnego przekazu.

11 Archiwum Główne Akt Dawnych (dalej: AGAD) w Warszawie, Komisja Rządowa Spraw Wewnętrznych i Policji (dalej: KRSWiP), sygn. 6278, „Akta tyczące się używania pieczęci urzędowej”, vol. 1: (1811-1838), s. 3 i nast. 
podejmowanych decyzji, czyli czymś w rodzaju ostatecznej redakcji prawa, tj. ostatecznie scalonym aktem prawnym pierwotnie spisanym $\mathrm{w}$ formie cząstkowych regulacji ${ }^{12}$.

Szersze kwerendy źródłowe obejmujące szczególnie archiwalia zgromadzone w kancelariach kościołów parafialnych (np. alegata, tj. zaświadczenia wystawiane narzeczonym przez urzędników stanu cywilnego - księży pełniących funkcje urzędników stanu cywilnego lub burmistrzów pełniących funkcje urzędników stanu cywilnego - stwierdzające okoliczności istotne dla zawarcia związku małżeńskiego) ujawniły, że dokumenty wystawiane w miastach Księstwa Warszawskiego były uwierzytelniane nie tylko za pomocą odcisków pieczęci z herbem sasko-polskim, ale także za pomocą odcisków pieczęci z innymi wyobrażeniami, w tym często z wyobrażeniami przedrozbiorowych znaków miejskich lub z wyobrażeniami znaków miejskich utworzonych po upadku Rzeczypospolitej, a przed utworzeniem Księstwa Warszawskiego, tj. między 1795 a 1807 r. ${ }^{13}$ Ta obserwacja został również zneutralizowana i wkomponowana w ogólny model sfragistyki Księstwa Warszawskiego ukształtowany przez stwierdzenie Mariana Gumowskiego o „dekrecie” z 29 kwietnia 1811 r. i jego treści. W tym przypadku badacze i znawcy usiłowali dowieść, że pieczęcie miejskie z przedrozbiorowymi znakami miast lub ze znakami opracowanymi w latach 1795-1806 powstały przed wydaniem regulacji w sprawie ujednostajnienia wyobrażeń pieczęci władz i urzędów miejskich przez wprowadzenie sasko-polskiego herbu dla wszystkich pieczęci wykorzystywanych przez władze i urzędy funkcjonujące w miastach księstwa ${ }^{14}$. Takie tłumaczenie wynikało z przeko-

12 K. Dorcz, Pieczęcie miejskie i gminne oraz wykonawcy pieczęci w Księstwie Warszawskim i Królestwie Polskim (do 1830 r.), „Rocznik Polskiego Towarzystwa Heraldycznego” 2003, t. 6 (17), s. 64.

13 Pieczęcie Księstwa Warszawskiego (z zasobu Archiwum Państwowego w Siedlcach), [prezentacja] wyb. i oprac. A. Rogalski, www.siedlce.ap.gov.pl; M. Adamczewski, Pieczęcie urzędowe wtadz lokalnych z obszaru Polski centralnej, cz. 3: Pieczęcie wtadz miejskich do roku 1950, Zgierz 2010, s. 106 i nast.

14 „Owa różnorodność form pieczęci nie trwała jednak długo. Wraz z utworzeniem Księstwa Warszawskiego sytuacja heraldyczno-sfragistyczna ustabilizowała się, a od $1811 \mathrm{r}$. na pieczęciach miejskich znajdować się miał wyłącznie herb sasko-polski”; M. Hlebionek, Pieczęcie miast Obwodu Nadnoteckiego (Netze Distrikt) w latach 1772-1806, ArchNet. 
nania o przyjęciu przez czynniki miarodajne okresu przejściowego, podczas którego pieczęcie władz i urzędów miejskich o wyobrażeniach innych od wzoru określonego w „dekrecie” z 29 kwietnia 1811 r. i wykonane przed przyjęciem prawa z 29 kwietnia 1811 r. miały być ważne, a wycofywanie ich z kancelarii miało nastąpić po ich zużyciu.

Przywołane do tego miejsca wątpliwości na temat chronologii i treści regulacji prawnej w sprawie ujednostajnienia pieczęci władz i urzędów miejskich przez narzucenie herbu sasko-polskiego stanowią dostatecznie wymowny i liczny zbiór przesłanek, aby rozważyć, czy na miejską sfragistykę Księstwa Warszawskiego nie należy spojrzeć z innej perspektywy niż ta prezentowana przez Mariana Gumowskiego w 1960 r. Rozważania rewidujące dotychczas obowiązujący model systemu sfragistycznego można prowadzić na dwóch płaszczyznach. W pierwszej kolejności należy ustalić, z jakich zbiorów pieczęci był złożony system sfragistyczny ukształtowany zwyczajem i normą dla pieczęci władz i urzędów miejskich w Księstwie Warszawskim. Tę część rozważań można oprzeć na bezpośredniej obserwacji zachowanych pieczęci, tj. tłoków i odcisków pieczętnych. Odczytanie legendy w jej części ogólnej pozwoli ustalić urzędowe nazwy dysponenta pieczęci wprowadzone na pieczęć przez grawera na żądanie zamawiającego, tj. dysponenta lub (co było praktykowane w scentralizowanych państwach) przez bezpośredniego zwierzchnika dysponenta, czyli w realiach czasów omawianych - przez podprefekta lub prefekta. Do kwestii identyfikacji władz i urzędów miejskich Księstwa Warszawskiego można podejść inaczej. Można odnaleźć regulacje prawne dotyczące miast i na ich podstawie odtworzyć strukturę władz i urzędów, która - jako skutek przyjętej normy - powinna zostać odzwierciedlona w materiale sfragistycznym. Założenie mówiące o bezpośrednim związku między przyjętą normą i jej wyrażeniem w materiale sfragistycznym zakłada funkcjonowanie sprawnie zorganizowanego państwa reagującego natychmiast i bezwzględnie na zmiany w zakresie stanu prawnego. Badacze i znawcy pieczęci wiedzą, że realizacja decyzji centralnych władz państwowych w sprawach pieczęci i herbów, nawet decyzji z klauzulą natychmiastowej wykonalności, wymagała

Naukowy Portal Archiwalny (www.archiwa.net), s. 13; M. Adamczewski, Pieczęcie urzędowe wtadz lokalnych..., s. 106 i nast. 
czasu, aby dysponenci na różnych szczeblach struktury władz i urzędów mogli dostosować swoje pieczęcie do obowiązującej normy. Tym samym nie można wykluczyć, że między wnioskami wyprowadzonymi z analizy wyobrażeń zachowanych pieczęci i wnioskami wyprowadzonymi z lektury normy regulującej sposób zorganizowania władz i urzędów w miastach księstwa nie będzie można postawić znaku równości.

Zachowane typariusze i odciski pieczęci z lat 1807-1815 pozwalają uznać, że krótki - niespełna 10-letni - okres istnienia Księstwa Warszawskiego w zakresie historii pieczęci był podzielony na podokresy. Wydaje się, że w ostatnich dniach 1806 i w pierwszych 1807 r. (wyprzedzając decyzje prawnie umocowanych władz centralnych księstwa) powstawały typariusze z polskim orłem państwowym lub z staropolskim godłem miejskim dopełnionym niejednokrotnie wyobrażeniem polskiego orła państwowego ${ }^{15}$. Po przejęciu władzy przez Fryderyka Augusta, króla Saksonii i księcia warszawskiego (22 lipca 1808 r.), a także po przyjęciu sasko-polskiego herbu jako oficjalnego znaku księstwa i po narzuceniu Księstwu Warszawskiemu konstytucji (22 lipca 1807 r.) do sfragistyki władz i urzędów księstwa został wprowadzony herb sasko-polski. Po klęsce Napoleona I w 1812 r. w Rosji i po abdykacji Fryderyka Augusta, jako księcia warszawskiego, czyli po wygaśnięciu oczywistej przyczyny wykorzystywania w księstwie kombinowanego herbu sasko-polskiego pieczęcie władz i urzędów księstwa zostały wyposażone w Orła Białego.

Tak zarysowany obraz heraldyki i sfragistyki Księstwa Warszawskiego należy uzupełnić o fakty związane z heraldyką i sfragistyką Galicji, czyli terenów włączonych do Księstwa Warszawskiego po wojnie z Austrią w 1809 r. Po zwycięskiej kampanii na terenie Galicji w przestrzeni publicznej pojawiły się złote orły napoleońskie, a nie polskie, białe orły państwowe ${ }^{16}$.

15 M. Adamczewski, Pieczęcie urzędowe wtadz lokalnych..., s. 111 i nast.

16 Rozkaz dzienny gen. Stanisława Fiszera, Szefa Sztabu Generalnego, Puławy z 2 VII 1809 r. [w sprawie m.in. opanowania Galicji i wprowadzania na jej terenie orłów Napoleona I w miejsce zdjętych austriackich znaków państwowych], Biblioteka Poznańskiego Towarzystwa Przyjaciół Nauk - dostęp z Wielkopolskiej Biblioteki Cyfrowej - www.wbc. poznan.pl; A. Wybranowski, W dzień zawieszenia ortów ztotych w kraju nazywanym Galicya, w: Pieśni z muzyka, marsze Wojska Polskiego z końca 18 i poczattu 19 wieku, z. 1: Stowa, zebrał i wyd. J. Horoszkiewicz, Kraków po 1889, s. 52-53. 
Francuskie orły o złotej barwie zawieszano na budynkach, zastępując nimi austriackie godła, wypełniano nimi pola pieczęci władz i urzędów, a szczególnie - pola pieczęci sądów. Wojsko wyzwolonej w 1809 r. Galicji posługiwało się symboliką napoleońską ${ }^{17}$, a nie polską. Stan ten był przejściowy i trwał do uregulowania statusu państwowego Galicji, niemniej w archiwalnej dokumentacji można dziś wyśledzić odciski galicyjskich pieczęci z orłem napoleońskiej Francji na polu i z napisem: NAPOLEON WIELKI w otoku ${ }^{18}$.

Dodatkowym utrudnieniem w badaniach ikonografii pieczęci władz i urzędów księstwa jest pewna zmienność zapatrywań czynników miarodajnych w sprawie zasięgu stosowania państwowej symboliki. W tym przypadku można zwrócić uwagę na pieczęcie fizyków (lekarzy) departamentowych i fizyków (lekarzy) powiatowych. Ci początkowo na jednoznaczne polecenie ministra spraw wewnętrznych zostali wyposażeni przez władze departamentowe w pieczęcie z herbem sasko-polskim, po czym w 1811 r. fizycy - na polecenie również ministra spraw wewnętrznych - mieli porzucić pieczęcie herbowe i zamiast nich przyjąć pieczęcie napisowe. Po interwencji niektórych prefektów minister uznał, że ministerialny reskrypt będzie miał znaczenie tylko dla nowych pieczęci, a stare, tj. herbowe pieczęcie fizyków miały być wykorzystywane dalej, aż do ich zużycia.

W rozważaniach prowadzonych w celu zrekonstruowania modelowego (uregulowanego prawnie) systemu sfragistycznego władz i urzędów Księstwa Warszawskiego szczególne znaczenie mają pieczęcie z herbem sasko-polskim. Z tego powodu na marginesie pozostawię inne pieczęcie występujące w dokumentacji z lat 1807-1815, tj. a) staropolskie pieczęcie przywrócone do służby po 1806 r., b) pieczęcie z czasów okupacji pruskiej

17 W zbiorach Muzeum Narodowego w Warszawie przechowywany jest rysunek orła z pieczęci 1. Pułku Piechoty Galicyjskiej (17. Pułk Piechoty Księstwa Warszawskiego). Orzeł - co wynika z odrysu - jest w swojej formie ogólnie orłem polskim, a nie orłem napoleońskim, ale trzyma w szponach błyskawice, które mogą prowadzić do skojarzeń z symboliką cesarstwa.

18 Dokument z czerwca 1811 r. z odciskiem pieczęci ze „złotym” orłem i napisem: NAPOLEN WIELKI - AP Kutno, Akta miasta Kutna, sygn. 42, „Zaświadczenia różne wydawane osiedlającym się rzemieślnikom" (1810-1816), k. 89. 
i c) pieczęcie wykonane po grudniu 1806, ale przed 22 lipca 1807 r., wyposażone w inne treści niż kombinowany herb Księstwa Warszawskiego.

W zasobie Archiwum Państwowego w Poznaniu są ujednostajnione tłoki pieczętne (wykonane zapewne przez jednego pieczętarza dla miast departamentu poznańskiego) z legendami rozpoczynającymi się konsekwentnie od ogólnej identyfikacji dysponenta: PIECZĘĆ MIASTA, dalej dopełnionej określeniem precyzującym w postaci jednostkowej nazwy własnej ${ }^{19}$. Do pieczęci z Archiwum Państwowego w Poznaniu można dołączyć zinwentaryzowane odciski bliźniaczych pieczęcie miast: Ślesina ${ }^{20}$, Gniezna, Czerniejewa, Żydowa ${ }^{21}$ i innych. Według kryterium dysponenta pieczęci w tym przypadku możemy zatem mówić o pieczęci miasta, czyli - posługując się przedrozbiorową terminologią - o pieczęci ogólnomiejskiej, ale $\mathrm{z}$ wyobrażeniem $\mathrm{w}$ postaci herbu państwa, a nie znaku miasta. Znane są także odciski pieczęci z herbem sasko-polskim i z napisami wskazującymi na burmistrzów albo burmistrzów policji (np. pieczęć burmistrza policji z Chodcza), których identyfikacja jednostkowa (przez własną nazwę miasta) była odnotowywana w dalszej części legendy. W poszytach dokumentów wytworzonych w latach 1807-1813 pojawiają się pieczęcie burmistrzów municypalnych, które miały pola wypełnione sasko-polskim herbem Księstwa Warszawskiego ${ }^{22}$.

Po ujawnieniu pieczęci władz i urzędów miejskich o różnych napisach spróbuję do zagadnienia systemu sfragistycznego w miastach Księstwa Warszawskiego podejść od strony regulacji prawnych, z których powinny wypływać wskazówki dotyczące rzeczywistego sposobu zorganizowania

19 Zbiór ttoków i stempli pieczętnych w zasobie Archiwum Państwowego w Poznaniu, red. P. Pokora, M. Hlebionek, Poznań 2015, nr 229 (Koźmin Wielki), nr 231-232 (Leszno), nr 321-322 (Poznań).

20 Archiwum Diecezjalne (dalej: AD) we Włocławku, Akta wizytacji kanonicznych dawnej archidiecezji gnieźnieńskiej, sygn. AAG 134, k. 564.

21 Archiwum Archidiecezji Gnieźnieńskiej w Gnieźnie (dalej: AA w Gnieźnie), Akta wizytacji kanonicznych dawnej archidiecezji gnieźnieńskiej, sygn. AAG 44, k. 18 (Czerniejewo, 1811), k. 77v (Gniezno, 1811), k. 338 (Żydowo, 1811).

22 AP w Kutnie, Akta miasta Kutna, sygn. 42, „Zaświadczenia różne wydawane osiedlającym się rzemieślnikom” (1810-1816), k. 9 (pieczęć burmistrza municypalnego miasta Lutomierska, 1810), k. 63 (pieczęć burmistrza municypalnego Łasku, 1811). 
systemu sfragistycznego. W prowadzonych tu obserwacjach pierwszeństwo należy oddać konstytucji księstwa ${ }^{23}$, a w dalszej kolejności - regulacjom niższego rzędu, które - częściowo sprzeczne z konstytucją - kształtowały ramy prawne decydujące o strukturze systemu sfragistycznego pieczęci miejskich władz i urzędów księstwa.

Napoleon I 22 lipca 1807 r. podzielił Księstwo Warszawskie na sześć departamentów, które składały się z powiatów i municypalności bez rozróżnienia - na poziomie regulacji - na municypalności miejskie i municypalności wiejskie ${ }^{24}$, choć - jak pokazała przyszłość - francuskich municypalności nie udało się zaszczepić w księstwie ${ }^{25}$. W prowadzonych tu rozważaniach duże znaczenie mają uwagi zawarte $\mathrm{w}$ konstytucji księstwa na temat municypalności miejskich. W municypalności władza była podzielona, jedna czesść władzy - władza administracyjna (wykonawcza) - należała do burmistrzów, czyli prezydentów municypalności, a druga - do rad municypalnych, których liczebność była uzależniona od wielkości miasta (tj. liczby mieszkańców). Konstytucja - po określeniu sposobu powoływania władz municypalności - nie precyzowała wzajemnych relacji i przede wszystkim nie wskazywała kompetencji prezydenta municypalności i uprawnień rady municypalności. Te szczegóły miały wyjaśnić regulacje niższego rzędu.

23 lutego 1809 r. została przyjęta organizacja Księstwa Warszawskiego na poziomie gmin miejskich i wiejskich ${ }^{26}$. Tym samym upadła koncepcja konstytucyjnego podziału administracyjnego kraju w tej części, która usuwała rozróżnienie najniższych jednostek administracyjnych na miasta i na gminy wiejskie. Municypalności powstały w czterech największych

23 Ustawa Konstytucyjna Xięstwa Warszawskiego, „Dziennik Praw” (Warszawa) 1810, nr 1-12, art. 64-68, s. XXXIV-XXXV.

24 M. Kallas, Samorzad miejski w dobie porozbiorowej, w: Herby miast polskich w okresie zaborów (1772-1918)..., s. 38-39.

25 P. Cichoń, Wptywy francuskie w administracji Księstwa Warszawskiego, „Zeszyty Naukowe Uniwersytetu Jagiellońskiego. Prace Historyczne” 140, R. 2013, z. 1, s. 12-13.

26 Wypis z protokótu Sekretariatu Stanu. W Patacu Naszym w Warszawie d[nia] 23. miesiąca lutego 1809 r., „Dziennik Praw” (Warszawa) 1810, nr 1-12, s. 201-209; P. Cichoń, op. cit., s. 12-13. 
miastach ${ }^{27}$. W pozostałych miastach $\mathrm{i} w$ innych miejscowościach zostały utworzone odpowiednio gminy miejskie i gminy wiejskie. Dla prowadzonych rozważań ma znaczenie zestawienie funkcji burmistrza w mieście i wójta na wsi, którym regulacja z 23 lutego 1809 r. jednakowo przyznała „[...] obowiązki miejscowej administracji [...]” wykonywanej „[...] pod dozorem i dyrekcją podprefekta powiatowego [...]”. Władza burmistrza rozpoczynała się od nominacji królewskiej, a władza wójta - od nominacji prefekta. W jednym paragrafie zostały wypunktowane administracyjne obowiązki burmistrza w mieście i wójta na $\mathrm{wsi}^{28}$. $\mathrm{Na}$ podstawie katalogu zadań wykonywanych odpowiednio przez burmistrza lub przez wójta można sformułować uwagę o charakterze wykonawczo-usługowym tychże wobec jednoosobowych zwierzchników z powiatów, departamentów i z kraju. Można przyjąć, że władza odpowiednio burmistrza i wójta stanowiła część „jednolitej władzy państwowej” sprawowanej jednoosobowo w gminach.

Drugim składnikiem współtworzącym strukturę władzy na poziomie gminy, a wyszczególnionym w regulacji z 23 lutego 1809 r., były odpowiednio rady miejskie i rady wiejskie. Ich członkowie otrzymywali nominacje od prefektów, którzy wskazywali radnych spośród kandydatów przedstawionych im przez zgromadzenia uprawnione do wyboru kandydatów. W miastach i gminach listy kandydatów były sporządzane przez osiadłych gospodarzy (posesorów).

27 Przywołana regulacja odnosiła się do stanu państwa sprzed wojny z Austrią w 1809 r. W lutym 1809 r. municypalności zostały powołane w Warszawie, Poznaniu, Toruniu i Kaliszu. W 1812 r. dołączono do nich municypalności w Krakowie, Lublinie i w Sandomierzu; P. Cichoń, op. cit., s. 12.

28 Regulacja z 23 lutego 1809 r. w $\$ 5$ wymienia zadania przypisane burmistrzom i wójtom i porządkuje je w kolejności od zadania najistotniejszego do zadania najmniej istotnego z punktu widzenia prawodawcy. W wykazie zostały wymienione następujące obowiązki burmistrzów i wójtów: a) podawanie (najśpieszniej) do wiadomości publicznej poleceń i rozkazów płynących od zwierzchnich władz do obywateli, b) nadzór nad majątkiem gminnym, c) odprowadzanie podatków, d) kierowanie robotami publicznymi, e) nadzór nad urzędami i instytucjami powołanymi do obsługi mieszkańców, f) troska o własność publiczną, g) organizacja sprawiedliwego podziału podatków i zabezpieczenie ich poboru oraz h) utrzymanie porządku publicznego w ramach burmistrzowskich lub wójtowskich uprawnień policyjnych. 
Z katalogu zadań powierzonych odpowiednio radom miast i radom gmin z regulacji z 23 lutego 1809 r. ${ }^{29}$ wynika, że radni podejmowali decyzje w sprawach, które dziś należą do własnych kompetencji lokalnego samorządu. W związku z ustanowieniem rad gminnych, a przede wszystkim ze względu na częściowo wolny sposób ich wyłaniania (oddolne rekomendowanie kandydatów na radnych) oraz po refleksji nad kompetencjami rad zasadne jest stwierdzenie o istnieniu w Księstwie Warszawskim gminnego samorządu, ale ograniczonego w zakresie powoływania i stanowienia miejscowego prawa ${ }^{30}$.

Przegląd regulacji na temat organizacji władz administracyjnych Księstwa Warszawskiego, a szczególnie na temat organizacji władz w miastach, prowadzi do refleksji, że od końca lutego 1809 r. w miastach Księstwa Warszawskiego funkcjonowały dwie władze uprawnione do podejmowania decyzji i w konsekwencji - do uwierzytelniania spisanych postanowień odciskiem właściwej pieczęci urzędowej. Burmistrz w miastach (prezydent w miastach municypalnych) stanowił władzę wykonawczą ściśle zespoloną z administracją państwową, a rada miejska - władzę uchwałodawczą, decydującą w niektórych sprawach istotnych dla mieszkańców gminy miejskiej.

$\mathrm{Na}$ tym etapie wnioskowania jest słuszne stwierdzenie, że jeśli władze Księstwa Warszawskiego zamierzały ujednostajnić system sfragistyczny władz i urzędów miejskich, to mogły to zrobić tylko przez przyjęcie regulacji w sprawie dwóch odmian pieczęci, tj. władze księstwa mogły ustanowić: a) pieczęcie burmistrzowskie (względnie - prezydenckie w miastach municypalnych) i równe im (w sensie prawnym) pieczęcie wójtowskie oraz b) pieczęcie rad miejskich.

29 Regulacja z 23 lutego 1809 r. w $\$ 12$ wymienia zadania przypisane odpowiednio radom miast i radom gmin i porządkuje je w kolejności od zadania najistotniejszego do zadania najmniej istotnego z punktu widzenia prawodawcy. W wykazie zostały wymienione następujące obowiązki rad: a) opracowywanie wniosków dla rady powiatu w sprawie zaistnienia okoliczności wpływających na wysokości gminnych ciężarów publicznych, d) opracowywanie opinii na temat funkcjonowania miejscowej administracji i opracowywanie katalogu potrzeb mieszkańców gminy w zakresie miejscowej administracji, c) szacowanie dochodów i wydatków gminnych i proponowanie sposobu rozłożenia składki, d) sprawdzanie rozliczeń burmistrza z kwot „użyczonych na potrzeby gminy”.

30 M. Kallas, op. cit., s. 40. 
Po ustaleniu normatywnie poprawnych rodzajów pieczęci władz i urzędów miejskich z lat 1809-1813 należy rozważyć, czy dla tychże dwóch odmian pieczęci prawodawca przewidywał wspólne wyobrażenie napieczętne, tj. ujednostajniony herb Księstwa Warszawskiego, czy też odwrotnie - zgadzał się na funkcjonowanie dwóch typów ikonograficznych pieczęci, tj. pieczęci z herbem państwa i pieczęci z innym wyobrażeniem (np. ze znakiem samorządowej wspólnoty miejskiej).

Jeśli zaufamy stwierdzeniom Mariana Gumowskiego z 1960 r., a także zgodzimy się z ich późniejszym wzmocnieniem, to przyjmiemy, że w scentralizowanym Księstwie Warszawskim wszystkie pieczęcie władz i urzędów zostały wyposażone w sasko-polski herb księstwa, a rodzaj herbu sasko-polskiego (liczba zewnętrznych elementów) na polu pieczęci miał pośrednio świadczyć o zaszeregowaniu dysponenta w strukturze władz lub urzędów. Według tego scenariusza na polach pieczęci prezydentów municypalności, burmistrzów miast i wójtów gmin wiejskich, a także na polach pieczęci rad minicypalnych, rad miast oraz rad gmin wiejskich powinien zatem występować herb sasko-polski.

Weryfikację tego założenia można przeprowadzić według dwóch postępowań - postępowania (w zasadzie) pośredniego na podstawie zachowanych odcisków pieczęci albo postępowania bezpośredniego na podstawie rządowych regulacji wykonawczych. Pierwszeństwo należy oddać rządowym regulacjom wykonawczym.

W aktowej dokumentacji z września 1809 r. zgromadzonej w miejskiej kancelarii w Turku zachowały się pisma wytworzone przy okazji wówczas podejmowanych decyzji w sprawie pieczęci władz i urzędów miejskich w zakresie właściwym dla kompetencji uczestników akcji prawnej ${ }^{31}$. W tym przypadku można mówić o sprawczej aktywności ministra spraw wewnętrznych oraz o wykonawczej aktywności prefekta departamentu kaliskiego i podprefekta powiatu warckiego. Bierną postawę - właściwą

31 Między rządową regulacją z 23 lutego 1809 r. a urzędową korespondencją z września 1809 r. odnalezioną w poszycie z Turku istniał związek przyczynowo-skutkowy. W korespondencji z września 1809 r. znajdowała się instrukcja, w jaki sposób strukturę władz i urzędów funkcjonujących w mieście od 23 lutego 1809 r. należało wykorzystać podczas tworzenia systemu sfragistycznego. 
odbiorcy służbowego polecenia - zachował burmistrz Turku. Przyjął on regulację, tzn. włączył ją do dokumentacji bieżącej urzędu z 1809 r. Ten sam poszyt (założony w 1809 r.) był dalej wykorzystywany w pierwszej połowie XIX w., czyli cezurą jego „przydatności” nie były wydarzenia polityczne z 1815 r. Być może ten fakt zdecydował, że kilka kartek z okresu Księstwa Warszawskiego przetrwało do czasów nam współczesnych.

Uważne kwerendy w zespołach pism przychodzących we wrześniu 1809 r. do innych miast Księstwa Warszawskiego, które zostały zebrane w kancelariach tychże ośrodków w poszyty na temat pieczęci i herbów, zapewne w większej liczbie potwierdzą sens ustaleń poczynionych na podstawie przekazu pochodzącego z jednego miasta. W tych rozważaniach najbardziej interesujące pozostaje pytanie, czy stan prawny znany z turkowskiej dokumentacji miejskiej był uniwersalny, czy też obejmował obszar tylko departamentu kaliskiego. Wiele przesłanek wskazuje, że ministerialna regulacja z 1809 r. miała charakter „ogólnopolski”, choć to stwierdzenie wymaga źródłowego potwierdzenia.

Treść reskryptu ministra spraw wewnętrznych zapewne z 15 września 1809 r. w sprawie pieczęci władz i urzędów miejskich jest znana z jego urzędowej kopii. Oryginalny reskrypt ministra został najpierw skopiowany w Warszawie i w ministerialnych odpisach wysłany do departamentów w badanym przypadku do prefekta w Kaliszu. W kaliskiej prefekturze warszawski egzemplarz reskryptu ministra został powielony i rozesłany do powiatów. W kancelariach powiatowych - w badanym przypadku w powiatowej kancelarii w Warcie - powstały kolejne kopie reskryptu i te zostały rozsyłane do samorządów, czyli do miast i gmin - w badanym przypadku do miast i gmin powiatu warckiego, a ostatecznie do Turku ${ }^{32}$.

Istotą omawianej regulacji sfragistyczno-heraldycznej $\mathrm{z}$ września 1809 r. jest urzędowe (tj. ministerialne) określenie podstawowej cechy tworzonego w Warszawie systemu sfragistycznego dla pieczęci władz i urzędów funkcjonujących w miastach Księstwa Warszawskiego. System miał być oparty na zapisach z konstytucji księstwa, ale przede wszystkim miał wynikać z przepisów prawa z 23 lutego 1809 r.

32 Edycja pism w sprawie pieczęci władz i urzędów miejskich z 1809 r. z dokumentacji aktowej miasta Turku została dołączona do artykułu w Aneksie źródtowym. 
Minister spraw wewnętrznych podzielił pieczęcie władz i urzędów gminnych (w badanym zakresie - pieczęcie władz i urzędów gmin miejskich) na dwie kategorie, tj. na pieczęcie wykonawczych władz zespolonych z administracją państwową (pieczęć prezydenta, burmistrza i wójta) oraz pieczęcie gminnych władz samorządowych (pieczęcie odpowiednich rad). Z uwagi na charakter źródła pochodzenia władzy nominującej (swobodna nominacja książęca - prezydent, burmistrz, lub specjalna nominacja (tymczasowa) ${ }^{33}$ prefekturalna - wójt, względnie zwykła nominacja prefekturalna z elementem udziału mieszkańców-posesorów gminy w elekcji kandydatów na radnych - radni), a także zakres obowiązków i kompetencji miejskiej władzy wykonawczej i miejskiej władzy uchwałodawczej minister zdecydował o utworzeniu dwóch odmian pieczęci - pieczęci (odpowiednio do miejsca): a) prezydenckiej, burmistrzowskiej (lub wójtowskiej) oraz b) pieczęci radzieckiej.

Pieczęcie miejskich, jednoosobowych władz i urzędów wykonawczych otrzymały wyobrażenia utworzone z herbu (zwykłego) Księstwa Warszawskiego i z napisu (odpowiedniego dla dysponenta): PREZYDENT MUNICYPALNY MIASTA NN lub BURMISTRZ MIASTA NN. W identyczne pieczęcie (w zakresie rodzaju przekazywanych głównych treści) zostali wyposażeni wójtowie w gminach wiejskich.

Fragment regulacji z września 1809 r. dotyczący posługiwania się pieczęcią z herbem sasko-polskim przez prezydentów, burmistrzów i wójtów nie budzi żadnych wątpliwości. Ten kierunek rozwoju gminnej sfragistyki Księstwa Warszawskiego został potwierdzony w innych regulacjach, a tu można przywołać drukowaną instrukcję prefekta departamentu bydgoskiego z 16 maja 1811 r. ${ }^{34}$ Wydanie instrukcji z 16 maja 1811 r. przez prefekta

33 W regulacji z 23 lutego 1809 r. użyty został przymiotnik provisorié przed informacją o nominacji prefekturalnej dla wójta. Przed informacją o nominacji prefekturalnej radnych prawodawca nie dodał żadnego dodatkowego określenia w celu uszczegółowienia charakteru czynności.

34 „Stosownie do odebranego reskryptu J[aśnie] W[ielmożne]go Ministra Spraw Wewnętrznych d[atowanego] d[nia] 10-go maja r[oku] b[ieżącego] uwiadamia WW[ielmożnych] podprefektów, że burmistrze w miastach i woyci po wsiach pieczęci z herbem Xięstwa Warszawskiego zwyczajnym i napisem Burmistrz lub Woyt używać mogą”; „Dziennik Tygodniowy Departamentu Bydgoskiego” (Bydgoszcz) 1811, nr 9 z 28 maja 1811 r., s. 101. 
departamentu bydgoskiego było spowodowane ciekawą dyskusją na temat stosowania pieczęci z herbem sasko-polskim, która była prowadzona od kwietnia 1811 r. między ministrem spraw wewnętrznych a niektórymi prefektami ${ }^{35}$.

Większe znaczenie niż ustalenia na temat treści pieczęci jednoosobowych władz i urzędów zarządzających w miastach i gminach mają informacje zawarte w drugiej części reskryptu ministra spraw wewnętrznych z września 1809 r. Minister stwierdził, że pieczęcie rad municypalnych i pieczęcie rad miejskich mają mieć wyobrażenie utworzone $\mathrm{z}$ herbu miejskiego, a nie z sasko-polskiego herbu Księstwa Warszawskiego.

Polecenie ministra spraw wewnętrznych w sprawie obligatoryjnego wykorzystywania na pieczęciach rad miejskich znaków samorządowych radykalnie zmienia sposób rozumienia tego segmentu sfragistyki Księstwa Warszawskiego. Kategoryczność dotychczasowych twierdzeń o wszechobecności herbów sasko-polskich na pieczęciach władz i urzędów miejskich, opartych m.in. na zdaniu Mariana Gumowskiego z 1960 r., należy zastąpić bardziej wyważonymi opiniami. Stwierdzenie, że władze centralne Księstwa Warszawskiego w połowie 1809 r. próbowały dopasować treść wyobrażenia pieczęci do charakteru władzy dysponenta, powinno stać się punktem wyjścia do dalszych analiz.

W wystąpieniach Krzysztofa Dorcza z 1996 (data referatu) i z 1999 r. (data publikacji referatu) ${ }^{36}$ została odnotowana źródłowa informacja, która powinna już dawno doprowadzić do rewizji opisu sfragistyki miejskiej Księstwa Warszawskiego. Krzysztof Dorcz przywołał fragment korespondencji ministra spraw wewnętrznych z $1811 \mathrm{r}$. z prefektem departamentu płockiego, w której został podniesiony problem m.in. pieczęci wykorzystywanych przez rady miejskie ${ }^{37}$. Prefekt departamentu płockiego w 1811 r. rozważał kwestię pieczęci rad miejskich i po wyrażeniu wątpliwości na temat ich treści zaproponował, „ażeby rady miejskie zatrzymały dawne pieczęcie mia-

35 AGAD Warszawa, KRSWiP, sygn. 6278, „Akta tyczące się używania pieczęci urzędowej", vol. 1: (1811-1832), s. 3 i nast.

36 K. Dorcz, Pieczęcie miejskie i gminne..., s. 64.

37 AGAD Warszawa, KRSWiP, sygn. 6278, „Akta tyczące się używania pieczęci urzędowej”, vol. 1: (1811-1832), s. 9-11; K. Dorcz, Pieczęcie miejskie i gminne..., s. 64. 
stom właściwe, których dotąd burmistrze używali, z napisem stosownym do ich urzędu (Rada Miasta N w Departamencie Ptockim)". Na pytanie w sprawie pieczęci rad miejskich prefekt departamentu płockiego otrzymał odpowiedź od ministra spraw wewnętrznych, że rady miast „mają używać dawnych pieczęci miastom ustalonych, których dotąd burmistrzowie używali z napisem stosownym do tego urzędu, to jest Rada Miasta NN".

Krzysztof Dorcz uznal, że zwrot „dawne pieczęcie miastom ustalone” należy interpretować w sposób właściwy dla przyjętego w literaturze założenia o bezwzględnej dominacji herbu sasko-polskiego w sfragistyce Księstwa Warszawskiego, dominacji także w sfragistyce miejskiej Księstwa ${ }^{38}$. W świetle przywołanych pism prefekta departamentu kaliskiego i podprefekta powiatu warckiego z 1809 r., odwołujących się do reskryptu ministra spraw wewnętrznych z 1809 r., można stwierdzić, że kierunek interpretacji Krzysztofa Dorcza nie był właściwy.

W ostatniej merytorycznej części artykułu spróbuję wyjaśnić jedną kwestię dotyczącą genezy stwierdzenia Mariana Gumowskiego na temat rozporządzenia władz Księstwa Warszawskiego z 29 kwietnia 1811 r. Skoncentruję się na dacie wydania domniemanej regulacji.

Data 29 kwietnia 1811 r. pojawia się w dokumentacji przechowywanej w AGAD w Warszawie ${ }^{39}$, którą w latach hitlerowskiej okupacji badał Marian Gumowski i sporządził z niej notatki. Data 29 kwietnia 1811 r. została zapisana na pierwszej karcie w zbiorze listów prefektów do ministra spraw wewnętrznych i kopii odpowiedzi ministra na te listy. Korespondencja została zebrana $\mathrm{w}$ poszyt dotyczący niektórych kwestii sfragistyki Księstwa Warszawskiego.

W pismach tworzących przywołany zbiór korespondencji wielokrotnie zostało podniesione zagadnienie wyobrażeń umieszczanych na polach pieczęci burmistrzów i wójtów, a także na polach pieczęci rad miejskich. Kwestie sfragistyczno-heraldyczne związane $\mathrm{z}$ pieczęciami burmistrzów

38 „Można zatem sądzić, że »dawne« pieczęcie już posiadały herb Księstwa Warszawskiego, a wspomniany dekret z 29 kwietnia o tym obowiązku jedynie przypominał"; K. Dorcz, Pieczęcie miejskie i gminne..., s. 64.

39 AGAD Warszawa, KRSWiP, sygn. 6278, „Akta tyczące się używania pieczęci urzędowej”, vol. 1: (1811-1832), s. 3. 
i wójtów oraz rad miejskich analizowane w $1811 \mathrm{r}$. były de facto zagadnieniami pobocznymi wobec zadania ustalenia formy pieczęci fizyków (lekarzy) departamentowych i fizyków (lekarzy) powiatowych. Uważam, że Marian Gumowski datę 29 kwietnia 1811 r. obecną w dokumentacji na temat pieczęci władz i urzędów księstwa i przede wszystkim występującą na początku poszytu uznał za określenie czasu przyjęcia regulacji, a dyskusję przeprowadzoną w innej sprawie, podczas której zostały tylko przypomniane regulacje na temat pieczęci burmistrzów i wójtów, przyjął za moment zredagowania rozstrzygających decyzji w sprawie pieczęci władz i urzędów miejskich.

Można uznać, że śledztwo w sprawie daty wprowadzenia jednej regulacji na temat pieczęci władz i urzędów miejskich Księstwa Warszawskiego, a także uszczegółowienie treści tejże regulacji nie ma - w skali „wielkiej” historii - większego sensu. Na rzecz da się spojrzeć inaczej. Ustalenie tego, że władze księstwa w 1809 r. podjęły decyzję o funkcjonowaniu w miastach dwóch typów pieczęci - pieczęci „miejskiej-państwowej” i pieczęci „miejskiej-samorządowej" - istotnie różniących się wyobrażeniami, pozwala zrozumieć praktykę pieczętowania dokumentów opuszczających kancelarie miejskie po 1809 r. dawnymi pieczęciami, a także tłumaczy pojawienie się w czasach księstwa nowych pieczęci miejskich (mniej lub bardziej) wiernie powtarzających pieczęcie z czasów I Rzeczypospolitej.

Ujawnienie państwowej akceptacji dla dwóch rozwiązań w ramach sfragistyki władz i urzędów miejskich Księstwa Warszawskiego umożliwia także wyjaśnienie niektórych wątków podniesionych w dyskusji prowadzonej na temat pieczęci władz i urzędów miejskich w II Rzeczypospolite $^{40}$. Na jednym z etapów kształtowania sfragistyki miejskiej II Rzeczypospolitej przyjęto (jak w czasach księstwa), że pieczęcie miejskiej władzy wykonawczej wykonującej niejednokrotnie zadania powierzone jej przez państwo powinny mieć na polu polskiego orła państwowego, a pieczęcie władz i urzędów miejskich sprawujących władzę wyłącznie w mieście - herb lokalnej wspólnoty samorządowej (historycznie uzasadniony herb miasta).

40 M. Adamczewski, Sfragistyka państwowa i samorządowa II Rzeczypospolitej Polskiej. Geneza niektórych rozwiązań prawnych, Warszawa 2019, s. 203. 
Na marginesie warto przypomnieć, że spór na temat wyobrażenia pieczęci fizyków (lekarzy) departamentowych i fizyków (lekarzy) powiatowych zakończony przesądzającymi decyzjami w $1811 \mathrm{r}$. miał swoją nową odsłonę w II Rzeczypospolitej ${ }^{41}$. Otwarte pozostaje pytanie, czy w międzywojniu polemika na temat ikonografii pieczęci lekarzy powiatowych pojawiła się w związku z rzeczywistymi uwarunkowaniami prawnymi funkcjonowania lekarzy, czy też została odnowiona w związku z uważnym odczytaniem źródeł z czasów Księstwa Warszawskiego.

\section{Aneks źródłowy}

Nazwa: Pieczęcie władz miejskich. Rozporządzenie Prefekta Departamentu Kaliskiego

Chronologia: wrzesień 1809 r.

Edycja: Podprefekt Powiatu Warckiego

Komunikuję Magistratowi w Turku [w] załączeniu in copia reskrypt Prześwietnej Prefektury [Kaliskiej] względem używania pieczęci w interesach rządowych z zaleceniem, aby się do takowego jak [najlepiej] w tej stosował i Radę Municypalną jako też [Radę] Miejską o tym uwiadomił.

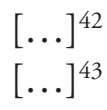

\footnotetext{
41 Ibidem, s. 114 i nast.

42 Podpis nieczytelny.

43 Podpis nieczytelny.
} 
Do Magistratu [w] Turku

[załącznik]

Copia

w Kaliszu, dnia 25. miesiąca września [1809] $]^{44}$

Prefekt Departamentu Kaliskiego

Uwiadamiając W[ielmożnego] Podprefekta, że J[aśnie] W[ielmożny] P[an] Minister Spraw Wewnętrznych reskryptem swym d[atowanym] d[nia] 15 $\mathrm{m}$ [iesiąca] [... ${ }^{45}$ postanowił, ażeby prezydenci municypalni i burmistrze w departamencie w rządowych ekspedycjach nie innych pieczęci jak tylko zwyczajnych rządowych używali, oświadcza:

1. że prezydenci municypalni mają odtąd mieć pieczęcie z herbem Księstwa Warszawskiego, a wokoło napis: „Prezydent Municypalny Miasta NN:” albo „Burmistrz Miasta NN:” również i Wójci po wsiach ustanowieni [być?] mający podobnych pieczęci używać mają,

2. rady municypalne i rady miejskie zaś mają mieć pieczęcie $\mathrm{z}$ herbem miast z napisem w koło: „Rada Municypalna Miasta NN:” albo „Rada Miejska NN:"

i wzywa W[ielmożnego] Podprefekt, ażeby stosowne w tej mierze do kogo należy wydał zalecenie

Rembowski [... $]^{46}$

Kowalski JG:

\footnotetext{
44 Odczyt daty niepewny.

45 Fragment tekstu nieczytelny.

46 Fragment nieczytelny.
} 
Do

W[ielmożnego] Zastępcy Podprefekta

Wartskiego

$N$ [umer]o 144.

$[\ldots]^{47}$ Septembri.

Oryginat:

AP Poznań Oddział w Koninie, Akta miasta Turku, sygn. 11, „W przedmiocie pieczęci urzędowych”, k. 2-3.

47 Fragment nieczytelny. 